\title{
ICT Attitudinal Characteristics and Use Level of Nigerian Teachers
}

\author{
Philip Olu Jegede \\ Institute of Education, Obafemi Awolowo University, \\ Ile-Ife, Nigeria \\ pojegede@oauife.edu.ng
}

\begin{abstract}
The study investigates the nat ure of relationship between ICT attitudinal constructs and use level of Nigerian teachers. A total of 467 teachers randomly drawn from teacher-training instit utions participated in the study. Two research instruments; Teachers ICT Attitudinal Scales and Teachers' Use of ICT Checklist were employed in collecting relevant information. Data collected were analysed using Multiple Regression Analysis and Spearman Correlation.

It was disc ussed that ICT Use Level of teachers is significantly related with each and the combination of att it ude constructs. The findings also revealed that perceived control factor, behavioural factors and defense fact ors contributed mostly to the prediction of ICT Use Level of teachers.
\end{abstract}

Key Words: ICT Attitude, Use Level, Constructs, Perceived usefulness

\section{Introduction}

Information and Communication Technology has enhanced teachers' professional knowledge, skill, and capabilities by extending their subject knowledge, enabling planning and preparation for teaching to be more efficient (Leach, 2005). Research has also shown that ICT enables effective leaming (Sutton, 2006). As a result of this, ICT is now recognized as an essential ingredient for creating 21 st cent ury learning environment. Educators worldwide are now hamessing the power of technology to transform learning and enhance results.

To foster classroom ICT integration, teachers have been identified to be a major factor in fostering classroom integration. This is because teachers constitute the facilitat ors and entrepreneurs in classroom ICT learning environment. For this reason, research efforts have concentrated on teacher-related factors such as ICT attitudes, self-efficacy, competence, etc. This is with the belief that each of this ICT-related behaviour will impact ICT use. For example Yuen, Law, and Chen (1999) identified teachers' positive attitude toward computers as an important factor in fostering computer integration and the enhancement of quality learning and teaching using computers.

Material published as part of this publication, either on-line or in print, is copyrighted by the Informing Science Institute. Permission to make digital or paper copy of part or all of these works for personal or classroomuse is granted without fee provided that the copies are not made or distributed for profit or commercial advantage AND that copies 1) bear this notice in full and 2) give the full citation on the first page. It is permissible to abstract these works so long as credit is given. To copy in all other cases or to republish or to post on a server or to redistribute to lists requires specific permission and payment of a fee.Contact Publisher@ InformingScience.org to request redistribution permission.
Kenzie, Delecourt, and Power (1994) opined that computer self-efficacy predicted computer use. Similarly, individuals who did not see themselves as competent ICT users were less likely to use ICT, in other words, competence is related to usage.

The missing fact in these findings is that the relationships between the constructs of each of these ICT behaviour compo- 
nents were not investigated. This may obscure important information and facts that may be needed in remedying identified problems. This information is what this study attempts to provide.

Previous endeavours in this context have investigated constructs of ICT attitudes and each of selfefficacy and competence (Jegede, 2007; Jegede, Dibu-Ojerinde, \& Ilori, 2007). What is yet to be added is the answer to the question: What relationship exists between each of ICT attitudinal constructs and use level of teachers?

Use level in this context implies the extent to which teachers use ICT for personal and professional practices. Chin and Marcolin (2007) emphasized the need for examining the actual phenomena of ICT usage. Phenomena of usage according to authors encompassed ICT usage pattern, quality of usage and quantity of usage. The present study measures usage in quantitative and qualit ative terms. Teachers in this study were those involved in pre-service teacher training institution in Nigeria, such as Colleges of Education and Universities' Faculties of Education.

The reason for choosing these populations is because good ICT behaviour when achieved among teacher educat ors will eventually be achieved on the student-teachers they teach. Thus tomorrow's ICT classroom environment will be guaranteed through these means. This is in consonance with Oliver (1994) who posited that unless student teachers have ICT role models, it will be impossible for them to integrate ICT into teaching. The sole objective of the study therefore is to ascertain the nature of relationship that exists between ICT att itudinal constructs and use level of teachers.

\section{Method}

\section{Participants and Setting}

Four hundred and sixty seven teachers selected from ten teacher education institutions (five Colleges of Education and five Universities) participated in the study. The sample covers all teaching cadre and subject discipline. T wo research instruments were employed to collect relevant data. These included Teachers ICT Attitudinal Scale (TICT AS) designed by Selwyn (1987) but adapted by Soh (1998) and Teachers' Use of ICT Checklist (TUIC). TICT AS is a 21-item fivepoint Likert scale with five constructs namely; affective components, perceived usefulness factor, behavioural factor, perceived control factor and defense factor.

Affective component assesses users' possible fear, apprehension and hesitation or discomfort in computer use. Perceived usefulness factor assesses whether the user finds the computer to be generally helpful, productive, imaginative and interest ing in relation to a person's work. Behavioural factor examines approach avoidance or whether computers are used frequently. Perceived control component borders on the extent to which the user is in control of the computer. Defense component examines the extent to which a person is free from defensive attitude against the use of computer. The total score yields the attitude of the teachers.

Teachers' Use ICT Checklist was originally developed for use with Singapore teachers by Soh (1998b). It consist s originally of 13 items out of which 11 were adopted. Two items were removed based on the judgment that they are not relevant to teachers' needs. Teachers were to indicate how often ICT has been used for a specific purpose in the past 3 months. The scores are organized into four sub-scores of Dat a processing, Word processing, Communications and Instruction. The two instruments were found to yield very good psychometric properties: Jegede (2006) obtained reliability coefficients of 0.90 and 0.75 for T ICT AS and T UIC respectively. The instruments were jointly administered on the teachers by the researcher and some field assistants. Four hundred and sixty-seven respondents returned the completed instruments. Data were analyzed using Pearson correlation co-efficient and multiple regression analysis. 


\section{Results}

The results are displayed in Tables $1-4$.

Table 1: Relationship between Teacher Educators' ICT Attitu de and Use Le vel.

\begin{tabular}{|c|c|c|c|c|c|c|c|}
\hline & 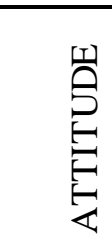 & 导 & $\begin{array}{l}\overrightarrow{\tilde{0}} \\
\tilde{0} \\
\text { ह } \\
0 \\
0\end{array}$ & 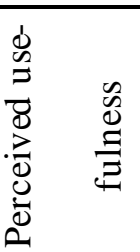 & 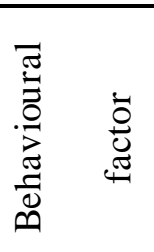 & 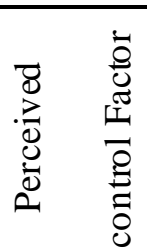 & 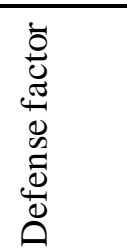 \\
\hline USE LEVEL & $.395 *$ & & & $.318 *$ & $.415^{*}$ & $.445^{*}$ & $.288 *$ \\
\hline
\end{tabular}

Note: * indicates significant relationship

Table 2: Analysis of Variance of Relationship between ICT Use Le vel and Component IC T Subscales

\begin{tabular}{|l|l|l|l|l|l|}
\hline \multicolumn{1}{|c|}{ Model } & Sum of squares & $\mathrm{df}$ & Mean square & $\mathrm{F}$ & Sig. \\
\hline Regression & 18137.781 & 6 & 3022.96 & 23.786 & .000 \\
\hline Residual & 58334.109 & 459 & 127.090 & & \\
\hline Total & 76471.89 & 465 & & & \\
\hline
\end{tabular}

Table 3: Summary of Multiple regression analysis of the relationship be tween ICT use le vel and a combination of in de pendent variables of attitude sub-scores

\begin{tabular}{|c|c|c|c|c|c|}
\hline Variables & $\mathrm{R}$ & $\begin{array}{c}\mathrm{R} \\
\text { square }\end{array}$ & $\begin{array}{l}\text { Adjusted } \\
\text { R square }\end{array}$ & $\begin{array}{c}\text { Standard } \\
\text { Error }\end{array}$ & Sig. \\
\hline $\begin{array}{l}\text { Affective component } \\
\text { Perceived usefulness } \\
\text { Behavioural factor } \\
\text { Perceived control Factor } \\
\text { Defense fact or }\end{array}$ & .487 & .238 & .227 & 11.273 & $<0.05$ \\
\hline
\end{tabular}

Table 4: Significant Tests of Regre ssion Weights of Inde pen dent Variables of Use le vel and Attitude.

\begin{tabular}{|l|l|l|l|l|l|}
\hline \multirow{2}{*}{ Variables } & \multicolumn{2}{l|}{$\begin{array}{l}\text { Understandardised } \\
\text { Coefficients }\end{array}$} & $\begin{array}{l}\text { Standardized } \\
\text { Coefficients }\end{array}$ & t & \\
\cline { 2 - 4 } & B & Std. error & Beta & & \\
\hline Constant & 9.794 & 1.903 & & 5.147 & .000 \\
\hline Affective Component & .00526 & .105 & -.208 & -.503 & .615 \\
\hline Perceived Component & .193 & .209 & .058 & .922 & .357 \\
\hline Behavioural Component & .932 & .245 & .311 & 3.812 & .000 \\
\hline Perceived Control Factor & 1.261 & .218 & .376 & 5.781 & .000 \\
\hline Defense Factor & .727 & .291 & .130 & 2.500 & .013 \\
\hline
\end{tabular}


From table 1, ICT attitude and use level of teachers have a significant relationship $r=.395$. The correlation coefficient between use level and each of the ICT att it ude subscores is significant with $\mathrm{P}<0.05$ yielding $\mathrm{r}=.274$ (use level and affective component), $\mathrm{r}=.318$ (use level and perceived usefulness), $r=.415$ (use level and behavioural factor), $r=.445$ (use level and perceived control factor) and $r=.288$ (use level and defense factor).

Furthermore, efforts were made to verify whether a combination of the att it udinal constructs significantly predict use level. This was done by analyzing the dat a collected using regression analysis. The analysis of variance of the multiple regression dat a gives an F-ratio of 23.786 which is significant at .05 level. This shows that a combination of attitude constructs is significantly related to ICT use level of teachers (table 2).

Table 3 shows the result of the regression analysis on the relationship between the dependent variable (use level) and the combination of the five independent variables. The result shows that predicting use level of teachers with the five independent variables (or attitudinal constructs) gives a coefficient of multiple (R) of .487 and multiple correlation square $\left(\mathrm{R}^{2}\right)$ of .237.These values are statistically significant at .05 level of significance, indicating that only 23.7 percent of the variance of ICT use level was explained by the combination of the five independent variables to predict ICT use level.

In addition, the Standard Regression weight (B), Standard Error of Estimate, Beta, T-ratio and the level of significance for each of the independent variables are presented in table 4, to further determine the relative power of each of the five independent variables to predict use level, only three of the variables to predict use level. Only three of the variables contribute largely to the prediction of use level. The Beta weight and t-ratio values for each independent variable show that behavioural component, perceived control factor and defense fact or contribute largely to the prediction of the ICT use level.

\section{Discussion}

A major finding of the study is that ICT use level and each of the attitudinal constructs are significantly related. Particularly, the study determined that behavioural factor and perceived control fact or have the strongest relationship. Autzen (2007) had earlier obtained that a negative att it ude towards an IT system will lead to little or no usage.

In addition, the study identified behavioural factor, perceived control factor and defense fact or as predictors of ICT usage among teachers. These appear similar to what predicted ICT self efficacy among teachers in Nigeria. Jegede (2007) reported that ICT self-efficacy among teachers was mostly predicted by perceived control and behavioural factors. It is common knowledge that self efficacy will result in use of ICT. Thus, it becomes consistent with reasoning that factors producing self efficacy will somewhat predict use level, though factors predicting use level may not necessarily predict self efficacy. This is because in Jegede (2007), virtually all the att it udinal constructs predicted self-efficacy but in the case of use level, perceived usefulness and ease of use were not found to predict use level. This opposed the usual Technology Acceptance Model which asserted that two particular beliefs; perceived usefulness and perceive ease of use are centrally import ant in predicting computer system user's accept ance behaviour (Hubonat \& Geitz, 1997), Technology Acceptance Model is in itself an old concept. What predicted usage more than a decade ago could have changed as technology becomes more and more popular.

The usefulness of technology is now universally acknowledged, thus perceived usefulness does not discriminate among today's technology users. The reason why perceived ease of use does not predict use level among teachers is not immediately apparent. This suggest $\mathrm{s}$ that there are other explanatory factors for example conceiving a technology as easy to use would not necessarily imply usage if the technology resources are not readily available. But the difference between the 
finding of Technology Acceptance Model and the present one could have also arisen from the subjects employed. The present study concentrates on teachers only while that of Technology Acceptance Model employed computer ICT in general.

Perceived control is a major predictor in this study probably because teachers' use of ICT is more or less a public one which tolerates less failure. This is not the case with users in many other professions. Thus a teacher's use of ICT will largely depend on the extent to which he is in control of the technology. The case with the predicting fact or of behavioural fact or is not farfetched. This is because the more teachers use ICT regularly the more they appreciate the usefulness, the more the affection, and the more they are in control as 'practice makes perfect'. Usoro (2000) succinctly presents this fact as he opined that if feelings of competence are increased in ICT provision, the use of ICT can be enhanced. Finally, defense factor was found to predict use level. This is possibly because freedom from defensive attitude against ICT that pave the way for regular use (behavioural factor) and sense of competence (perceived control) is the beginning of use.

A major limitation of the study is the fact that the respondents in the study covered six states in just one of the six geo-political zones of the country. A more elaborate study covering all the zones is needed for a wider generalization.

\section{References}

Autzen, B. (2007). Quality of usage as a neglected aspect of in formation technology acceptance. Retrieved November 30, 2007 from http://wifo1.bwl.unimannheim.de/fileadmin/files/publications/working_paper_2007_QualityOfUsage.pdf

Chin, W. W., \& Marcolin,B. (2001). The future of diffusion res earch. The DATABASE for Advances in Information Systems, 32(3), 7-12.

Hubona,G. S., \& Geitz, S. (1997). External variables, beliefs, attitude and information technology, Usage behaviour. Proceedings of the 30th Annual Hawaii International Conference on System Sciences, IEEE Computing Society Press, Los Alamitos.

Jegede, P.O. (2007). Computer attitudes as correlation of computer sel f-efficacy among South-Western Nigerian higher education teachers. Paper presented at Sixth International Internet Education Conference, Cairo, Egypt, September 2-4, 2007.

Jegede, P. O., Dibu-Ojerinde, O. O. \& Ilori, M. O. (2007). Relationship between ICT competence and attitude of some Nigerian lecturers. Education Research and Review. Retrieved November 30, 2007 from http://www.academicjournals.org/ERR/PDF/pdf\%202007/Jul/Jegede\%20et\%20al.pdf

Kenzie, M., Delecourt, M., \& Power, S. (1994). Computer technologies; Attitudes and selfefficacy across undergraduates disciplines. Research in Higher Education, 35(6), 745-768.

Leach, J. (2005). Do ICTs enhance teaching and learning in South Africa and Egypt? Retrieved November 30, 2007 from http://www.digitalopportunity.org/article/view/125462/1/

Moron, J. W. \& Kim, Y. G. (2001). Extending the TAM for a world-wide-web context. Information and Management, 38, 217-230.

Oliver, R. (1994). Information technology courses in teacher education; The need for integration. Journal of Information Technology for Teacher Education, 3(3), 135-146.

Selwyn, W. (1997). Students' attitude toward computers. Validation of a computer attitude scale for 16-19 education. Computer \& Education, 28(1), 35-41.

Soh, K. C. (1998a). Cross cultural validity of Selwyn Computer Attitude Scale. Unpublished manuscript

Soh, K. C. (1998b). Teacher use of computers checklist. A validation study. Unpublished manuscript.

Sutton, B. B. (2006). Pedagogy and curriculum. Retrieved November 30, 2007 from http://www.digitaldivide.net/news/view.php?HeadlineID=701 
Usoro, A. (2000). Attitude as a factor for the use of in formation and communication technology for global planning. Computing and Information Systems, 7, 58-64.

Van der Heijden, H. (2001). User acceptance of hedonic information systems. MIS Quarterly, 28(4), 695704.

Yuen, H. K, Law, N. \& Chen, H. (1999). Improving IT training for serving teachers through evaluation In G. Cumming, T. Okamoto, \& L. Gomez (Eds.), Advanced research in computers and communication in education (pp. 441-448). Amsterdam: IOS Press.

\section{Biography}

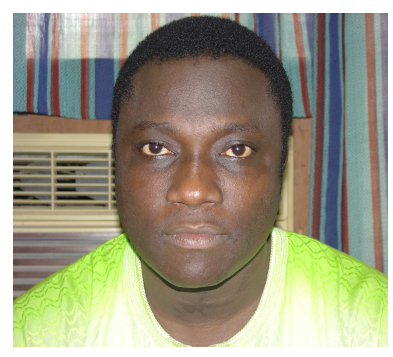

Dr. Philip Jege de is Senior Lecturer of ICT Curriculum in Institute of Education, Obafemi Awolowo University, Ile-Ife, Nigeria. He obtained B.Sc and M.Sc de grees from University of Lagos, Nigeria. He later vent ured into the discipline of Education bagging $\mathrm{M}$. Ed and Ph. D degrees of Obafemi Awolowo University, Ile-Ife, Nigeria. His research interest is in ICT Education particularly among pre-service teachers. He's been a speaker in national and internat ional conferences. Before his present appointment, he had lectured in a College of Education and a Polytechnic School. 